\title{
From Rags to Riches: Corporate Elite of Pakistan from 1947-1970
}

\author{
Ayesha Shoukat \\ Assistant Professor, Islamia University of Bahawalpur, Pakistan.
}

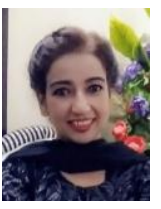

\begin{abstract}
This paper focuses on the historical narrative of the establishment and development of corporate elite of Pakistan in almost twenty years which became a symbol of a success story to follow in those years. Literature cover this area under the concept of industrial development and resource allocation but less work is done on it with the Power Elite approach under political economy perspective. This paper argues that it is due to collusion and contestation of the existing elite of that time, that a new elite, Corporate, was established and then was nurtured by other elites to safe guard their own vested interest. The private investors who turn up to be big business groups within two decades used networking among themselves via family links and playing active role in politics. This act of developing corporate elites was aided by international affairs which in turn enhanced the economic and political influence of business groups.
\end{abstract}

Keywords: Corporate Elite, Industrial policy, Political system, Regime shift, Networking.

JEL Classification: E02, B52, L16, L52, D72, D74.

Citation | Ayesha Shoukat (2020). From Rags to Riches: Corporate Elite of Pakistan from 1947-1970. Asian Journal of Social Sciences and Management Studies, 7(1): 8-16.

History:

Received: 11 November 2019

Revised: 16 December 2019

Accepted: 21 January 2090

Accepted: 21 January 2020

Licensed: This work is licensed under a Creative Commons

Attribution 3.0 License (cc)

Publisher: Asian Online Journal Publishing Group

Contents

1. Introduction

Funding: This study received no specific financial support.

Competing Interests: The author declares that there are no conflicts of interests regarding the publication of this paper.

Transparency: The author confirms that the manuscript is an honest, accurate, and transparent account of the study was reported; that no vital features of the study have been omitted; and that any discrepancies from the study as planned have been explained.

Ethical: This study follows all ethical practices during writing.

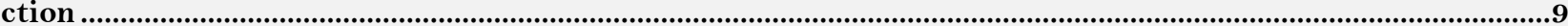

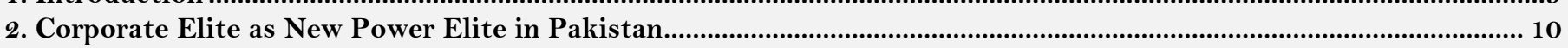

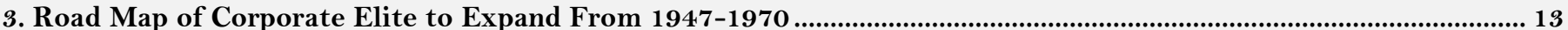

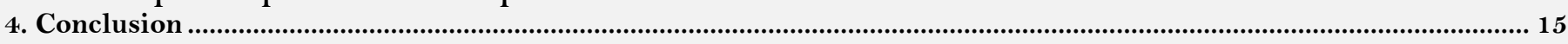

References 


\section{Contribution of this paper to the literature}

This paper provides the success story of the corporate elite of Pakistan in early twenty years of the creation of Pakistan. It had theoretically proved the application of the Power Elite Theory of Mills (1956) on the real scenario of collusions and contestations among power elites of this part of the world and how it had given birth to a new Elite i-e, Corporate Elite. Who later on played a vital role in crafting the ruling elite of this society.

\section{Introduction}

There are two primary reasons for this focus on corporate elites. First, is the fast growth of this elite group in a country which had started with almost zero industrial heritage and infrastructure. Second is the ability of corporate elites to acquire control of 66 per cent of total industrial assets, 70 per cent of the insurance sector and 80 per cent of the banking industry within the first twenty years of Independence in 1947, a factor that changed the basic structure of the economy and political horizon of the country (Haq, 1976). A few corporate elites had contributed to the Pakistan movement, but how much their participation helped them to acquire top positions in the corporate sector has yet to be answered. For example, among the founders of the Muslim League there were a few Muslim manufacturers, the most notable being Adamjee Pirbhai Aga Khan ${ }^{1}$ (later elected as the first president of the League), despite being head of the Ismaili community². He was closely connected to leading Muslim manufacturers in Bombayo (Hussain, 1985).

The other aspect to be investigated is how these corporate elites then utilized their influential position in society and government to further develop their corporate base. To create a complete picture of the development of the corporate sector, there is a need to understand how new business groups entered the corporate sector and went on to become major enterprises. ${ }^{3}$

\subsection{Corporate Elite}

Useem (1983) analyzed the corporate elite of America and Britain and defined them as those comprising men and (a few) women who were in a position to exercise a major influence on the decisions and policies of large companies. The early 1980 s was a time when the governments of both countries followed a "supply side economics" philosophy and radical reductions in state social services and traditional safety nets. Useem's work focuses on the resultant strategies and activities of the large corporations towards the government's pro-business activities. He discussed in detail how corporate elites obtained power and then manipulated the governance of political parties in their own interest. He emphasized multiple in-house strategies opted by corporate elites in the shape of philanthropic activities and nonprofit organizations to sustain their strong stance and position in the society. These corporate elites whom he called an "inner circle" ${ }^{4}$ obtained the leadership of major business associations, own most of the media channels and financially support political parties and candidates. This study assesses the corporate elite of Pakistan under these domains.

In Pakistan, corporate elites played a critical role at the time of independence and have been an important power source since then. However, the interesting thing about the corporate elites of Pakistan is the contestations among them. Analysts consider these contestations among the corporate elites of East and West Pakistan as the major reason for the division of the country in 1970 and the creation of Bangladesh. The corporate elites of West Pakistan had been so powerful and influential in policy decisions that it was not considered wrong when the East Bengal Professional Elite (EBPE) accused corporate elites of treating their province as a colony that could be exploited for its raw materials and resources (Ali, 2001).

Pakistani corporate elites have been facing numerous internal and external issues. As emerging elites, they have always been under the social influence of bureaucrats and landlords. Being corporate people, their focus involved securing high profits; but they have been entangled in caste and class conflicts too. In an interview with me, one famous political analyst, Dr. Imran Ali, who has extensively studied business groups of Pakistan mentioned that corporate elites have always been involved in unproductive social competition with feudal lords who have long had a lavish life style, one they inherited from their ancestors. Pakistan is a society of social classes. Landlord elites historically are following a lifestyle of lavish living. Corporate elites, after securing good profits, strove to compete with each other and other elites by spending extended on lavish lifestyles. At the start of industrial development, such wasteful expenditure should not have been the case as the country needed reinvestment of profits in the industry rather than nonproductive expenditures.

To win the race of extravagant lifestyles, Pakistan's corporate elite tried to be in the limelight by spending extraordinary on lavish villas and cars, rather than industrial units. For example, during the development decade (1958-68), over US $\$ 300$ million was spent on the import of private cars while US\$20 million was spent on public transport. At that time private luxury housing accounted for $80-90$ per cent of the construction that took place in the country (White, 1974).

\footnotetext{
${ }^{1}$ The Adamjee group, though a corporate elite in the early days of Pakistan, lost its position and today is no longer among the top companies. In less than two decades, the Adamjee group established and managed over forty industrial and financial enterprises in East and West Pakistan, Burma, Thailand, Malaysia, Lebanon and the United Kingdom. In 1971, due to ethnic and social differences between East and West Pakistan, a civil war broke out. This ultimately resulted in the bifurcation of the East wing, leading to the creation of independent Bangladesh. The newly-formed socialist government of Bangladesh took control of all major industrial and financial institutions. The Adamjee family lost all its assets in Bangladesh and was compelled to shift its group headquarters to Karachi. On the Western front, the Group became the subject of public criticism following the propaganda of anti-trust laws concerning monopolistic business families of the country. As a consequence of this movement, a large segment of its assets in West Pakistan was also lost under Prime Minister Z.A. Bhutto's nationalization programs in 1974. Source: (http://www.adamjees.net/history.aspx)

2 The Ismailis are the only Muslim business community working in the geographical area which later became Pakistan. Members of this group also have a business presence in Calcutta and Bombay.

${ }^{3}$ For example, the Jahangir Saddique Group, Schon Group and Best Way Group have been operating in the corporate sector for more than 30 years and now are among the top in the list of industrialists.

${ }^{4}$ Useem identified the inner circle as those individuals who have been personally approached by senior government officials with a request for reactions to a "shortlist" of candidates for appointment to major advisory bodies or even top administrative posts.
} 
According to Mahboob-ul-Haq, for all practical purposes, 22 families had become by 1968 both the planning commission and the ministry of finance for the private sector. They pre-empted most investment permits, import licenses, foreign credits and government patronage because they controlled or influenced most of the decisionmaking forums handing out such permissions. They had virtually established a stranglehold over the system and were in a position to keep out new entrepreneurs.

Ethnic disputes among corporate elites had not let them gain the economic position which they could have secured if they had worked together and with other elite groups. Such ethnic and social factors justified their shape till the 1980s. However, after this period when the local corporate elite had to face global competition, along with the neo-liberal policies of the government, how they responded to these issues and what new strategies were followed by those big corporate names has still not been researched. As Dr. Kaisar Bengali said in 2009, there had been no industrial policy for the last 30 years after the country was transformed from a developmental state to a security state ${ }^{5}$. This research focuses on these factors which had an impact on the corporate elite and how they sustained in it.

\subsection{Tools used by Corporate Elites}

Corporate elites around the world always use networks as a tool to collude with each other and other power elites to expand their profits and businesses. Davis et al. (2003) did research the networking patterns of corporate elites and the stability of these ties. They found that the aggregate connectivity of the network is remarkably stable and appears to be an intrinsic property of the interlock network, resilient to major changes in corporate governance. They used concepts from "small world" analysis to explain their findings that the structure of the corporate elite is resilient to macro and micro changes affecting corporate governance.

For networking analysis, the sample studied and considered by Mills (1956) was a small set of private schools, while Groton and Exeter provided an essential agency for socializing and organizing members of the upper class, and Mintz and Schwartz (1985) argued for a special role for money-center banks in knitting together corporate directors. Davis et al. (2003) suggest that the small-world organization of the corporate elite is an emergent property of networks-qua-networks and requires no coordinating mechanism. These scholars suggest that no specific mechanism is followed by corporate elites for networking and it keeps changing as per the events occurring in a country. The other school of thought involving the "old school boy" network argues that corporate elites in each society follow certain channels and networks to develop links and liaisons with others which are later useful for future progress (Bell, 1994; Schaede, 1995).

Berle and Means (1932) explored the evolution of big business through the legal and economic lens and argued that in the modern world those who legally have ownership over companies have to be differentiated from those who control them. Later, Domhoff (1967) employed Berle and Means' concept of ownership and control in his investigation of the corporate structure of America, specifically to trace the flow of power, through elite-based networks of the country. While studying Pakistan's business groups' ownership and control structure, it was found that as most of them are family business groups so control was with the major shareholders. The average shareholding by family members and the associated companies of the group came up to 30-35 per cent. This makes the boards of directors who primarily constitute family members the major decision-makers and they control the managerial decisions as well.

\section{Corporate Elite as New Power Elite in Pakistan}

During the early years after its independence, Pakistan faced four crises that impaired its development: the war with India over Kashmir, communal rioting, urban destruction and a massive influx of refugees into West Pakistan (Wilcox, 1968). While these events were taking place, the corporate sector was in the process of reviving itself, following the migration to India of 80 percent of Karachi's business giants who were Hindus. Ali and Malik (2009) note that in Lahore, out of 215 businesses, 167 were owned by non-Muslims and in Karachi 80 percent of land and all foreign trade were controlled by non-Muslims. Urban trade and commerce were managed by Hindus who migrated to India creating a serious gap in the areas of banking, insurance, education, trade and industry (Sharif, 1966). Meanwhile, a majority of those who had migrated to Pakistan were small Muslim traders with little or no business experience.

In 1947, out of a total 14,569 industrial establishments that existed in the subcontinent, only 1,406 units were in Pakistan (including the region which is now Bangladesh). Most of these industrial units were of little importance such as flour and rice mills and cotton ginning factories. There was also the serious problem of limited financial resources without which it was impossible to proceed with any kind of industrial development plan. To counter these problems, the government emphasized establishing export-oriented industrial enterprises. The two major hurdles in establishment of these enterprises were the lack of business-oriented human capital and the poor industrial infrastructure.

Bureaucrats actively moved to resolve these problems. First, they tried to train and support businessmen with non-business backgrounds by establishing the Pakistan Industrial Development Corporation (PIDC) and Pakistan Industrial Credit and Investment Corporation (PICIC). Shafqat (1999) and White (1974) argue that the establishment of PIDC and PICIC was a core factor that led to the creation of financial/industrial groups that came to be known as the "22 families" in the 1970s. According to White (1974) the top 43 groups listed on the Karachi Stock Exchange (Pluta and Frederiksen, 1980) received 11 of 43 businesses divested by the PIDC in East Pakistan and eight of 17 firms in West Pakistan. The big companies owned by these 22 families included Karnaphuli Paper Mills and Burewala Textile Mills (Dawood family), Jauharabad Sugar Mills (now Kohinoor Sugar Mills) (Saigol family), Karachi Gas Company (Fancy family), Charsada Sugar Mills (Hoti family), Adamjee Chemical Works, Adamjee Industries, Adamjee High Grade Paper and Board Mills, Nowshera and at least six jute mills which were built by WPIDC (West Pakistan Industrial Development Corporation). 
Although East Pakistan contributed 70 percent of the total jute production of a united India, it lacked a welldeveloped jute-processing enterprise. In West Pakistan, the major crop was cotton but only three processing firms existed in the region (Ali and Malik, 2009). The geographical area that came under Pakistan was only associated with the production of raw agricultural products. The processing firms that were established were in areas that remained with India after partition. Table 1 outlines the division of industrial units in 1942 in the areas which were separated as India and Pakistan.

Table-1. Division of industrial units in India and Pakistan in 1942.

\begin{tabular}{l|c|c}
\hline Industrial units as per products & India & Pakistan \\
\hline Cotton & 857 & 15 \\
\hline Jute & 3 & 0 \\
\hline Sugar & 176 & 15 \\
\hline Paper mill & 19 & 0 \\
\hline Iron and steel works & 36 & 0 \\
\hline Glasswork & 112 & 8 \\
\hline Cement and lime works and potteries & 57 & 8 \\
\hline
\end{tabular}

Source: Eastern Economist (1942).

These figures do not include small factories and workshops making light consumption goods, such as hosiery and knitwear, electrical fittings, rugs, shoes and leather goods, handicrafts in wool, silk, embroidery, in cities like Lahore. In these businesses, Pakistan was not badly under-represented. The single industry of any note was the production of sports goods in Sialkot in West Punjab (Spate, 1948). There was little prospect for industrialization except in agricultural-based industries such as cotton ginning and milling, flour, food processing and jute mills in Eastern Pakistan, though even here these enterprises were encountering serious difficulties. Considering the limited available options for creating an industrial sector, the business groups of that time focused on agriculturalrelated industries such as the establishment of Dawood Cotton Mills in 1951.

There were a few major Muslim-owned enterprises in the region. One of them was the Adamjee family, which had played a major role in the Pakistan movement, though largely in the form of behind-the-scenes financial support. Nevertheless, the absence of a business-oriented class provided immigrant Muslims an opportunity to invest in textile industries previously controlled by Hindus. In West Pakistan, the initial business movers after partition settled in Karachi as it was a port city and the hub of business activities. They chose not to settle in Punjab as the government selected this region to settle homeless migrants from India.

In East Pakistan, migrant re-settlement was not an issue and the corporate elite of that area were Hindu Marwaris, Europeans and a few Bengali Muslims. Muslim migrants with business backgrounds settled in Karachi in spaces once occupied by a Hindu business class. They were mostly Memons from Gujarat (India) who belonged to the Sunni Muslim sect; they were extremely hard-working with a long history of involvement in business. Others included the Dawoodi Bohras from Bombay, the Khoja Ismailis from Bombay and East Africa and the Khoja Ishnashris, all of whom belonged to the Shia sect. The religious sects they belonged to continues to be a factor when it comes to decision-making in business ventures. A region which developed as a business centre after Karachi was Lyallpur, near Lahore (Punjab), where the Chinioties spearheaded business activities. Chiniot is a small town near Lyallpur (now renamed Faisalabad). The Chinioties started a textile industry as the major cash crop in Punjab was cotton.

\subsection{Pakistan's Business History}

To understand the business history of Pakistan, it is necessary to determine the origins of these business groups from united India that emerged under British rule. Historians conventionally argue that the Indian capitalist class was more prone to collaborate with foreign capital and that they apparently faced "no major conflict" in adapting to its presence (Gardezi and Rashid, 1983; Ali, 2004; Bose and Jalal, 2004). Other historians challenge this as a neo-Marxist position, arguing that though Indian capitalists were weak and dependent, they struggled with imperialism and made use of crises in the world economy, such as the world wars and the Great Depression, to emerge as an independent force (Raman, 2014). The literature on business activities in India focuses on enterprises in Bombay and Calcutta. Among the business groups of prominence in Pakistan were those that had migrated from Bombay and Calcutta.

In Pakistan, as in India, the industrialists were usually members of old trading families. These families continue to dominate Pakistan's corporate sector. However, the method used to develop their enterprises was a legacy of the British, the "agency firm"6 (Lamb, 1955). Families like Adamjee, Valika and Habib were involved in trading, insurance and banking from the colonial period.

Industrial capitalism was an unintended by-product of British economic and political policy. British presence in India was to capitalize on its raw materials. These materials were used for British products manufactured for export. To facilitate global trade, British needed ports, especially in Calcutta and Bombay. Calcutta was used for jute-related trade and Bombay for cotton-related products. The production areas for both these products later became Pakistan, but processing units were launched in Calcutta and Bombay as these cities had ports.

The industrial groups in India belonged to different religions. Most of the groups were Hindus and Jains and the others were Christians, Muslims and Zoroastrians. Among these business groups, only two ethnic groups were involved in the cotton industry in the 1850s; they provided cotton to Bombay's textile manufacturers. Those were the Parsis, who had migrated from Persia almost 1200 years ago and were a relatively small group, and the Gujratis, a subgroup of the larger Hindu community. These two groups were selected to control the cotton

\footnotetext{
${ }^{6}$ The managing agency conducted extensive trading operations and ran industrial plants, about which no quantitative information is available. Some of these ventures were incorporated as "public" companies with listed shares on stock exchanges and were required to publish annual statements. A long-term contract between the managing agency and each related company allowed the agency to determine overall company policy and to intervene in day-to-day decisions.
} 
industry due to their business knowledge and access to the ports, being residents of nearby areas. The Parsis had the advantage of being closer to British businesses because of their command of the English language.

In 1854, C.N. Davar, a Parsi banker and trader with many British contacts, built the first cotton textile mill. It soon matched many other factories in Bombay and Gujarat. Later, the Parsi industrialist J.N. Tata and his family entered into heavy industries. Since then, Hindu and Parsi business interests expanded, gradually transitioning from trade to industry (Lamb, 1955). This is similar to the developments in Pakistan with the only difference being that the traditional industrial community were Hindus who upon migration to India were replaced by Muslim traders. Since they had no strong industrial and manufacturing experience, those groups with some measure of business experience like the Adamjee and Habib Groups captured much of the market in the emerging economy.

The prominent elite groups who significantly participated in the Pakistan movement were landlords, educated secular urbanities and the commercial minorities. These commercial minorities became business groups by expanding their businesses in the first decade. Papanek (1962) explains that before 1947, 70 percent of industry owners belonged to the trade sector (buying and selling finished products and gaining a commission) but later became entrepreneurs. He also mentioned that 27 percent of the industrialists were Helai Memons who comprised only 0.3 percent of the total population.

Prior to partition, most of the business groups that participated in the growth of Pakistan's industry had their headquarters in Calcutta or Bombay. After partition, only three cities became the hub of all industrial activities: Karachi (a port city), Lyallpur (the city with a large number of manufacturing firms) and Lahore (the hub of Punjab). Inevitably, business families settled in these three cities. 40 percent of all industrial workers soon were to be found in these three cities. Table 2 details the background of the top business groups which either migrated to Pakistan in 1947 or were situated there well before partition.

Table-2. Background of industrial families.

\begin{tabular}{l|l|l|l|l}
\hline Business group & Community & Family Origin/Area & Settled & HQ location pre 1947 \\
\hline Adamjee & Memon & Kathiawar/ Jetpur & Karachi & Calcutta \\
\hline Dawood & Memon & Kathiawar/Bantwa & Karachi & Bombay \\
\hline Saigol & Punjabi Shaikh & West Punjab/ Chakwal & Lahore & Calcutta \\
\hline Valika & Dawoodi/Bohra & Bombay & Karachi & Bombay \\
\hline Colony & PunjabiShaikh/ Chinioti & West Punjab/ Chiniot & Lahore & Lahore \\
\hline Fancy & Khoja Ismaili & Kathiawar & Karachi & East Africa \\
\hline Bawany & Memon & Kathiawar/ Jetpur & Karachi & Rangoon \\
\hline Crescent & Punjabi Shaikh/ Chinioti & West Punjab/ Chiniot & Lyallpur & Delhi \\
\hline Beco & Punjabi & East Punjab & Lahore & Batala \\
\hline Wazir Ali & None, Syed) & West Punjab/ Lahore & Lahore & Lahore \\
\hline Amin & Punjabi Shaikh & West Punjab & Karachi & Calcutta \\
\hline Nishat & Punjabi Chinioti & West Punjab/ Chiniot & Lyallpur & ----- \\
\hline Hoti & Pathan Landlord & Charsadda & Charsadda & Charsadda \\
\hline Fateh & Marwari & Gujurat & Karachi & ----- \\
\hline Isphani & None) & Iranian & Karachi & Calcutta \\
\hline Karim & Bohras & Bombay & Karachi & ---- \\
\hline Habib & Khoja Isnasheri & Bombay & Karachi & Bombay \\
\hline Hyeson & None) & Madras & Madras \\
\hline Source: Kochanek (1983) & & & \\
\hline
\end{tabular}

Source: Kochanek (1983)

Table 2 shows that of the top 18 business groups, six belonged to Punjab and eight were situated in Karachi including the Memon, Khojas and Dawood families. Out of these 18 business groups, three did not belong to any community and had no background in business or trade, pre-partition. From the other two provinces of Khyber Pakhtunkhwa and Baluchistan, there was only one business group, owned by a landlord. Table 2 also indicates that although Punjab had a number of business groups, these were not landlord-turned-corporate elites; rather, they had a history of being in business in Delhi, Calcutta and Lahore.

Most of these business groups were associated with the cotton industry (West Pakistan) or jute industry (East Pakistan). When Pakistan came into being, there were only 16 textile companies out of which only 12 were in operation. It grew to 70 in 1957 as industrial development took place. By 2013, there were 596 textile mills out of which 442 were in operation. The export revenue of the textile industry contributed a large share to the GDP of Pakistan. Kochanek (1983) noted that the fastest growing families were not the Isphahanis, Haroon or Rahimtoola ${ }^{7}$, but Dawood, Saigol, Jalil (Amin), Adamjee, Shaikh, Fancy, Valika, Bawany, Bashir (Crescent) and Wazir Ali. The political leaders of the Muslim League traditionally kept business and politics separate (Kochanek, 1983).

The business groups selected as case studies in next chapter represent each industrial community. The Dawood Group represents the Memon group, which had a strong business background in Bombay, while the Sehgal group is a Punjabi sheikh group from Calcutta, now settled in Lahore. To represent a group which has no community backing, but came up as a strong group, the Wazir Ali group was selected, now known as the Packages Group ${ }^{8}$. A group which had community links but no business background before the partition is the Nishat Group, located in Faisalabad. These groups are diverse in nature, representing all communities, based in all three industrial cities and have had different levels of historical support from the state.

7 These were the leading business groups at the time of the creation of Pakistan. The Isphanai Group held the proud tag of launching Orient Air Ways which later became the national air carrier, Pakistan International Airline (PIA). The Raheemtoola group was originally based in Bombay and was involved in trading since the late $19^{\text {th }}$ century as well as in politics. Sir Ibrahim Rahimtoola was Mayor of Bombay and first Indian Speaker of the Indian Imperial Parliament. His son, Habib Ibrahim Rahimtoola was a close associate of Mohammed Ali Jinnah, the founder of Pakistan. Habib served Pakistan as its first High Commissioner to the United Kingdom in 1947. The Haroon Group was also closely linked with Jinnah and the Pakistan Movement. The founder of this group, Abdullah Haroon, was a British Indian politician who contributed to nurturing Muslims in economic, educational, social and political fields in South Asia. Later, his son Yousaf Haroon, founder of the Dawn Group, played an active role with Jinnah in the Pakistan Movement. ${ }^{8}$ Famous as Packages Group, after its leading packaging firm, Packages Limited. 


\section{Road Map of Corporate Elite to Expand From 1947-1970}

This section explains in detail the effect of different policies adopted by democratic and authoritarian governments in Pakistan from 1947 till 1970. How the corporate elite changed their strategies and adapted to policy decisions will be highlighted in the discussion. This needs to be understood in light of the situation of resource allocation to the corporate sector under each regime.

\subsection{Emergence of Corporate elite in First Bureaucratic Regime, 1947-58}

The Pakistani government followed a liberal trade policy to strengthen newly-established business groups. Businesses incentives were offered to secure investments. This trade policy of the first bureaucratic regime focused on establishing facilities for the processing of domestically produced raw materials. The reason for focusing on these industries was because Pakistan was able to produce agriculture products some 50 to 70 percent cheaper than global prices. By the 1950s, Pakistan's agriculture industries were one of the largest and cheapest. The profits earned from this industry allowed for the import of advanced manufacturing units to further industrialization. Pakistan sought to transition from exporting cheap raw materials and importing finished goods made by the same raw material at a high price to manufacturing final goods. This push for industrialization came at the expense of the landlords and the agriculture sector. Papanek (1962) noted that development of the industrial sector was due to four major reasons:

1. The government's ability to maintain law and order and prevent massive capital flight by enforcing import controls and providing overhead facilities.

2. A small proportion of the population was accustomed to responding to market incentives.

3. Institutions and value systems were supportive of entrepreneurial activities.

4. A political system which did not get unduly worried by high prices, high profits and the presence of foreign enterprises.

Table 3 presents the expansion of industrial assets from 1947 to 1959. The value of investments in the corporate sector increased tenfold, from Rs.580 million to Rs.5020 million. This expansion indicated the gap in the economy waiting to be tapped by businesses. Papanek (1962) developed an index to explain the growth of industrial assets. This index indicated an almost six-fold expansion of industrial assets within ten years, from 1949 to 1959 see Table 3. This meant that investments were increasing in both the manufacturing sector and industrial assets.

Table-3. Growth of Industrial Assets, 1947-1959.

\begin{tabular}{c|c|c}
\hline Year & Million (Rs.) & Index \\
\hline 1947 & 580 & 17 \\
\hline 1949 & 820 & 36 \\
\hline 1951 & 1280 & 57 \\
\hline 1953 & 2030 & 100 \\
\hline 1955 & 3510 & 124 \\
\hline 1957 & 4360 & 143 \\
\hline
\end{tabular}

Source: Papanek (1962).

From 1953 to 1960, manufacturing had grown more rapidly in Pakistan than in any other country according to the United Nations' statistics, except for Japan. Papanek (1964) Conducted a survey in 1960-61 involving a lengthy questionnaire completed by 255 industrialists belonging to different geographical areas. They were, according to the Census of Manufacturing Industry (CMI), 8 percent of the total 3170 firms at that time. Papanek's study provided primary data derived from the survey and census report and offered evidence of a phenomenal increase in the industrialization of Pakistan in the first decade, from 1947 to 1957. However, that industrialization was concentrated in West Pakistan. This is evident in Table 4 derived from a study by Guisinger (1976) about the industrialization pattern that followed the early years.

Table-4. Pattern of Industrialization in Pakistan, 1950-70.

\begin{tabular}{l|c|c|c|c}
\hline Factors & \multicolumn{4}{c}{ West Pakistan } \\
\hline Structural characteristics & $\mathbf{1 9 5 0}$ & $\mathbf{1 9 6 0}$ & $\mathbf{1 9 7 0}$ & $\mathbf{1 9 7 0}$ \\
\hline Per capita GNP & 65 & 75 & 100 & 110 \\
\hline Population (million) & 80 & 100 & 130 & 60 \\
\hline Share of Industry (expected) & .12 & .13 & .17 & .16 \\
\hline Share of Industry (actual) & .07 & .12 & .16 & .21 \\
\hline Source: Guisinger (1976) & & &
\end{tabular}

Source: Guisinger (1976).

Table 4 outlines industrial expansion in Pakistan in the first twenty years. It shows that an under-developed country lacking industrial firms as well as skilled human resources in labour and at managerial levels could find methods to progress. Pakistan did make the world wonder about its industrial development. Growth was primarily because a group of private entrepreneurs were ready to take the risk and initiative to invest and they showed an ability to efficiently organize the required capital and skilled manpower. These early entrepreneurs competed little with each other because of the ample market opportunities that were available. Competition arises when companies face saturation, which was not the case with Pakistan in its early days. Moreover, local and international markets were open and these entrepreneurs did not face the problem of excess supply. This could only happen as the market gave them space to flourish and take advantage of growing international and national demand.

According to the approach developed by Maniruzzaman (1966), Chinroy, Soligo (Lewis, 1965) and others, the growth pattern of industrialization can be attributed to import-substitution, export expansion and domestic demand. The Korean War brought wealth to Pakistan. Businesses sold raw materials to the anti-communist nations and then invested their profits in the manufacturing of consumer goods. 
A number of reasons account for Pakistan's rapid economic growth soon after independence: the favourable impact of growth in the world economy, the liberalization policy of the 1950s, the economic role of the state and the mobilization of savings (Ahmad, 1959; Baqai, 1979; Amjad, 1982). These factors played a role but cannot be considered as major reasons for the massive expansion of the industrial sector. The core reason was the role of the state involving its capacity to increase investments in manufacturing firms by allocating resources for projects which were essential for development (McCartney, 2011). Industrialization was further generated with the reinvestment of profits, including those accruing from trade. Industries were initially established by funds derived from approximately 40 percent of trade profits. Only 10 percent of finances came from commercial banks. As Papanek (1962) noted, dominant family-owned businesses allowed an enterprise to go public after they had skimmed off the high profits of the earlier years, providing them with funds for new investments in high profit areas. The most important source of financing was reinforced earnings, which provided almost half of the industrial investments between 1958 and 1959.

The corporate elites who could exploit this gap were old business groups as well as the small traders who were emerging as businessmen. The main problem for industrial development was the huge foreign exchange required to establish such enterprises in Pakistan. This was generated from the export of jute, produced in East Pakistan. However, the collusions between corporate and bureaucratic elites of West Pakistan hindered this foreign exchange from being invested for further industrial expansion in East Pakistan. This ignited tensions between East and West Pakistan from the early 1950s, a situation created by elites.

In the mid-1950s, Prime Minister Suharwardy tried to reduce this tension by sanctioning more import licenses to East Pakistan's corporate groups and by allotting aid for the modernization of ill-equipped industries. However, West Pakistan's business groups did not accept it and sent a protest about this to President Iskandar Mirza. The corporate elite of West Pakistan took advantage of the rifts between President Mirza and Prime Minister Suharwardy by seeking an alliance with the former (Maniruzzaman, 1966). This alliance became one reason for the overthrow of Suharwardy. This resulted in the short-lived interim government of Chandigarh (7 October 1957 to 16 December 1957) who cancelled all import licenses and grants awarded to East Pakistan. A similar situation occurred under Prime Minister Noon's regime (16 December 1957 to 7 October 1958), before Martial Law was imposed by General Ayub in October 1958. The early collusions and contestations among corporate and political elites played a significant role in shaping the business structure of current Pakistan.

The bureaucratic elite also played a significant role in these collusions. Bureaucrats had complete autonomy to allocate funds and award licenses to industrialists as well as brief them about future business decisions such as where to expand and what to produce. This policy of offering incentives to develop the industrial sector continued until the 1960s. This policy did not lead to equitable growth, but resulted in concentration of wealth by certain groups. As the import licenses and approvals to establish industrial enterprises were controlled by the bureaucratic elite, they issued those contracts to corporate elites with whom they had personal contacts. By the mid-1950s, corporate groups owned major financial sectors like banks ${ }^{9}$ and insurance houses. Financial capital was thus easily available to them, compared to other emerging groups. This environment created by government and some business groups proved a major problem for new entrants in the corporate sector attempting to establish businesses.

\subsection{Corporate Elite Expansion under Military Regime}

In the 1960s, Pakistan had a mixed economy model in which the state set up industries that were later transferred to private businesses. The pursuit of profit inspired these private businessmen to invest and expand in other sectors of the economy. Economic reforms were initiated in agriculture, education, law, land, trade and taxation. The initial results were quite spectacular and the model attracted academics as well as policy-makers from other countries. One of the distinguishing features of the mixed economic model was that Pakistan had a strong bureaucracy that guided and directed the private sector. The Planning Commission of the 1960s was a powerful technocratic institution assisted by foreign economic experts. Corruption and parochial interests had not permeated the higher levels of decision-making to the degree that it subverted economic progress and institution building.

Though this industrial development increased GDP, it could not be sustained and growth was not distributed evenly. As discussed, during the military regime led by General Ayub arose the issue of wealth concentration in the hands of a few families. Society was clearly divided between elites and the lower and middle classes. Since the middle class was emerging in this era, and as Ayub was a follower of modernization, this allowed intellectuals and the middle class to articulate their thoughts in public forums. These forums became the reason for Ayub's fall. Wilcox (1970) however, was of the view that the reason for Ayub's fall was primarily due to disputes that arose among military elites. Inequitable forms of development led to political decisions based on the vested interests of those holding power. In this situation, even risk-taking entrepreneurs stepped back from investing or moved to other countries, especially after the government's nationalisation policy began.

On a related point, since Ayub's regime, the military had developed an independent corporate empire. Siddiqa (2007) argues that to ensure control of power, military elites always desired to expand their economic interest. One example of state patronage was the accusation that Ayub had awarded numerous rents to his son, Gouhar Ayub, and his father-in-law, to help set up Gandhara Industries.

Khandker (1973) measured Pakistan's income distribution in the first twenty years and found more unequal distribution of income in urban areas compared to rural areas. He also argued that there was increased inequality of wealth in the form of corporate industrial assets. He found that a mere 47 stockholders owned 100 percent of corporate assets. These 47 stockholders consisted of 14 groups and 33 individuals see Table 5 . 
Table-5. Distribution of number of principle stockholders and total assets by size, 1970 .

\begin{tabular}{c|c|c|c|c|c|c|c|c}
\hline \multicolumn{9}{c}{ Number of Principle stocks } \\
\hline Size of Assets & Single & Group & Total & $\mathbf{\%}$ & $\begin{array}{c}\text { Single Co. } \\
\text { Million Rs. }\end{array}$ & $\begin{array}{c}\text { Group Million } \\
\text { Rs }\end{array}$ & $\begin{array}{c}\text { Total } \\
\text { Million Rs }\end{array}$ & $\begin{array}{c}\text { \% } \\
\end{array}$ \\
\hline Less than 25 & 10 & - & $10(10)$ & 21 & 149 & - & 149 & 3 \\
\hline $25-50$ & 11 & $1(2)$ & $12(13)$ & 26 & 364 & 147 & 411 & 10 \\
\hline $50-100$ & 9 & $3(6)$ & $12(15)$ & 26 & 604 & 272 & 876 & 20 \\
\hline $100-150$ & 2 & $4(9)$ & $6(11)$ & 13 & 255 & 539 & 794 & 18 \\
\hline $150-200$ & 1 & $1(3)$ & $2(4)$ & 4 & 190 & 152 & 342 & 8 \\
\hline $200-300$ & - & $2(5)$ & $2(5)$ & 4 & - & 483 & 483 & 11 \\
\hline $300-400$ & - & $2(9)$ & $2(9)$ & 4 & - & 654 & 654 & 15 \\
\hline $400-a b o v e$ & - & $1(4)$ & $1(4)$ & 2 & - & 621 & 621 & 15 \\
\hline Total & - & $14(38)$ & $47(71)$ & 100 & - & 2768 & 2768 & 100 \\
\hline
\end{tabular}

Notes: Values in brackets present the total number of companies.

Source: Khandker (1973).

Thirty four stockholders (with less than 100 million rupees) owned 33 percent of assets, 10 stockholders (with 100 to 300 million rupees) owned 37 percent and three stakeholders (with above 300 million rupees) owned 30 percent. This concentration of wealth allowed these business groups to indulge in illegal activities to expand their businesses. Papanek (1962) contends that investors offered bribes and were even willing to pay a legal surcharge of over 100 percent to import machinery.

Concentration of wealth among the big 22 families proved that power games had been played to enhance the personal interests of elites. In spite of high growth rates, people were unhappy with the military government and the middle class, specifically university youths who started voicing the need for equal rights and opportunities for everyone. Many reasons can be attributed for the fall of Ayub's government. One of the reasons was the decision to withdraw from the 1965 war, after the Tashkand agreement ${ }^{10}$. Although Ayub blamed Zulfiqar Ali Bhutto (then Pakistan's Foreign Minister) for this ${ }^{11}$, his accusation later fuelled Bhutto's success in the elections. Bhutto's main issue in the 1970 elections was the plight of youths and the working class whose votes made him the next Prime Minister. Bhutto's major support was from West Pakistan. In East Pakistan, support was primarily for Mujeeb Ur Rehman ${ }^{12}$. Given the conflicts between the military and Mujeeb, the latter helped Bhutto to become the Prime Minister ${ }^{13}$. The reason the military was in conflict with Mujeeb was his continuous pressure on Ayub regarding the latter's six point agenda which did not entail giving him regional autonomy.

\section{Conclusion}

The two main strategies adopted by a business group to expand were, first by creating family links with each other; this also served as a means to secure connections with other power elites. Through this method, the corporate elite also obtained the benefit of becoming a double elite, securing their position in different domains. This was observed in the links between the Nishat and Kohinoor Groups. Through marriage ties, the Kohinoor Group secured access to state rents because of the political contacts that Mian Mansha of Nishat Group had with Nawaz Sharif.

Second, the expansion and evolution of business groups had implications on politics under different regimes. Domestic politics was deeply shaped by foreign affairs and the role of international elites in Pakistan. General Ayub provided strong support to newly-emerging industrialists and helped them become corporate elites. This act of developing corporate elites was aided by international affairs which in turn enhanced the economic and political influence of business groups. The Korean War and the spread of Communism in Asia drew America to Pakistan, enhancing General Ayub's position. Ayub used this opportunity to strengthen the position of the military elite, while foreign aid and investments helped expand the industrial sector. Bhutto's nationalization policy was also not an act taken in isolation. As the world was moving towards a socialist approach to development, Bhutto's leftist and populist policy agenda became the reason for winning elections and the country came under the control of a democratic government

\section{References}

Ahmad, M., 1959. Government and politics in Pakistan: Pakistan Publishing House.

Ali, I., 2004. Historical impacts on political economy in Pakistan. Asian Journal of Management Cases, 1(2): 129-146.Available at: https://doi.org/10.1177/097282010400100203.

Ali, I. and A. Malik, 2009. The political economy of industrial development in Pakistan: A long-term perspective. Lahore Journal of Economics, 14: 29-50.Available at: https://doi.org/10.35536/lje.2009.v 14.isp.a3.

Ali, I.A., 2001. Business and power in Pakistan. Power and Civil Society. Karachi: Oxford University Press.

Amjad, R., 1982. Private industrial investment in Pakistan 1960-1970. Cambridge. UK: Cambridge University Press. pp: xvi+258.

Baqai, M., 1979. Pakistan's pattern of development and prospects. Pakistan Economic and Social Review, 17(3/4): 1-62.

Bell, D.A., 1994. Lawyers and citizens: The making of a political elite in old regime france. Oxford University Press on Demand.

Berle, A.A. and G.C. Means, 1932. The modern corporation and private property. New York: Macmillan.

Bose, S. and A. Jalal, 2004. Modern South Asia: History, culture, political economy. London: Routledge Press.

\footnotetext{
${ }^{10}$ The Tashkent Declaration of 10 January 1966 was a peace agreement between India and Pakistan after the Indo-Pakistani War of 1965. Peace was achieved on 23 September, following the intervention of the super-powers who pushed these two nations to a cease fire.

${ }^{11}$ These differences over the Tashkent Declaration eventually led to the removal of Bhutto from Ayub's government. Bhutto launched his own party, the Pakistan People's Party (PPP). Although Ayub was able to quell public criticism, there is no doubt that the Tashkent Declaration greatly damaged his image, one of many factors that led to his downfall.

${ }_{12}$ Bhutto created a coalition government with Mujeeb who agreed Bhutto would assume the Presidency while he would serve as Prime Minister. The military government and General Yahya Khan were kept unaware of these developments. Yahya ordered a military action in East Pakistan. The Military Police arrested Bhutto and put him under house arrest. Mujeeb was charged in a military court.

${ }^{13}$ Yahya spoke to Mujeeb and Bhutto separately. Mujeeb did not agree on any point made by Yahya, but Bhutto's stance was the need for dialogue between the concerned parties prior to any assembly session. For Bhutto, there were three crucial actors in this dialogue: the military, PPP and the Awami League. Unless there was a constitutional settlement between the three parties, the assembly session could not be convened. This hard stand by Bhutto suited the military and vested interests in West Pakistan.
} 
Davis, G.F., M. Yoo and W.E. Baker, 2003. The small world of the American corporate elite, 1982-2001. Strategic Organization, 1(3): 301326.Available at: https://doi.org/10.1177/14761270030013002.

Domhoff, G.W., 1967. Who rules America? USA: Prentice Hall.

Gardezi, H.N. and J. Rashid, 1983. Pakistan, the roots of dictatorship: The political economy of a praetorian state. Karachi: Zed Press.

Guisinger, S.E., 1976. Patterns of industrial growth in Pakistan. The Pakistan Development Review, 15(1): 8-27.Available at: https://doi.org/10.30541/v15i1pp.8-27.

Haq, M.U., 1976. The poverty curtain: Choices for the third world. New York: Columbia University Press.

Hussain, A., 1985. Pakistan: The crisis of the state. Islam, Politics and the State: The Pakistan Experience. pp: 195-228.

Khandker, R., 1973. Distribution of income and wealth in Pakistan. Pakistan Economic and Social Review, 11(1): 1-39.

Kochanek, S.A., 1983. Interest groups and development: Business and politics in Pakistan: Karachi: Oxford University Press.

Lamb, H.B., 1955. The indian business communities and the evolution of an industrialist class. Pacific Affairs, 28(2): 101-1 16.Available at: https://doi.org/10.2307/3035375.

Lewis, S.R., 1965. Domestic resources and fiscal policy in Pakistan's second and third plans. The Pakistan Development Review, 5(3): 461495.Available at: https://doi.org/10.30541/v5i3pp.461-495.

Maniruzzaman, T., 1966. Group interests in Pakistan politics, 1947-1958. Pacific Affairs, 39(1/2): 83-98.Available at: https://doi.org/10.2307/2755183.

McCartney, M., 2011. Pakistan-the political economy of growth, stagnation and the state, 1951-2009. Routledge.

Mills, W.C., 1956. The power elite. The power elite. Newyork.

Mintz, B.A. and M. Schwartz, 1985. The power structure of American business. University of Chicago Press.

Papanek, G.F., 1962. The development of entrepreneurship. The American Economic Review, 52(2): 46-58.

Papanek, G.F., 1964. Industrial production and investment in Pakistan. The Pakistan Development Review, 4(3): 462-490.Available at: https://doi.org/10.30541/v4i3pp.462-490.

Pluta, J.E. and P.C. Frederiksen, 1980. Nationalization of industry and other factors affecting the growth and centralization of public expenditure in Pakistan: Office for Public Sector Studies, Institute of Latin American Studies, University of Texas at Austin.

Raman, K.R., 2014. Business, ethnicity, politics, and imperial interests: The United Planters' Association of Southern India, 1893-1950. Business History Review, 88(1): 73-95.Available at: https://doi.org/10.1017/s0007680513001438.

Schaede, U., 1995. The" Old Boy" network and government-business relationships in Japan. Journal of Japanese Studies, $21(2): 293-317$.

Shafqat, S., 1999. Pakistani bureaucracy: Crisis of governance and prospects of reform. The Pakistan Development Review, 38(4): 9951017.Available at: https://doi.org/10.30541/v38i4iipp.995-1017.

Sharif, M.R., 1966. Modern economic development of Pakistan. Dacca: Mullick Brothers.

Siddiqa, A., 2007. Military Inc. Inside Pakistan's military economy. New York: Oxford University Press.

Spate, O.H.K., 1948. The partition of India and the prospects of Pakistan. Geographical Review, 38(1): 5-29.Available at: https://doi.org/10.2307/210736.

Useem, M., 1983. Business and politics in the United States and United Kingdom. Theory and Society, 12(3): 281-308.

White, L.J., 1974. Industrial concentration and economic power in Pakistan: Princeton: Princeton University Press.

Wilcox, W., 1968. Political change in Pakistan: Structures, functions, constraints and Goals. Pacific Affairs, 41(3): 341-354.Available at: https://doi.org/10.2307/2755003.

Wilcox, W., 1970. Pakistan in 1969: Once again at the starting point. Asian Survey, 10(2): 73-81.Available at: https://doi.org/10.1525/as.1970.10.2.01p0553b. 